\title{
The Presence of Poetry in the Family Genogram
}

\author{
Maria Arlene de Almeida Moreira ${ }^{1}$, and Ceneide Maria de Oliveira Cerveny ${ }^{2}$ \\ Pontifícia Universidade Católica de São Paulo, SP, Brasil
}

\begin{abstract}
The authors bind the employment of previous experiences with the use of Poetry in family therapy (2015), with the use of genogram (2005). They made a poem with each onarratives of the stories of family (10 participants). Exemplifying the example of the use of Poems in the waiting room in United Kingdom (1996), the authors report the development of the method and the results after this experience.
\end{abstract}

Keywords: Poetry; Genogram; Rebuilding the family's stories.

Titre: La Poésie Est Dedans. Le Génograme Et Les Histoires Familliaires.

Résumé. L'expérience avec l'usage des poèmes avec les familles dans le set therapéutique (2015) et l'usage du génograme comme un producteur du connaissance cientifique (2005) sont les points du départ des autheurs pour raconteur les histoires, les mythes et les intérations familliaires. Les auteurs s'utilisent des poèmes pour reconstruire les histoires des 10 (Dix) familles participants. Ils citent l'example du project Poèmes dans la Salle d'Espére (1996), qui a eи lieu au Royaume- Uni et racontent le process, les sentiments soulèvés et les résultats de l'experience.

Mot-Clés: Génograme; Poésie; Réconstruction.

\section{Introduction}

This report has many sources of inspirations. Nowadays we are living a way of life plenty of technology, however we are human been not machine, and we are able to find poetry in our life, not only pain and suffer. We are lucky to share moments with all those that came to us in different relational spaces as professional, in family, with friends, in group of supervision with colleges or in the academic life. Be grateful for all the contributions that are coming from those places of conviviality is something that arise in us the feeling of humanity and a way to expose the poetry of life that exists inside each story of those meetings.

The family, the genogram and the poetry. The genogram has been used as a tool in Family Therapy. It shows the structure and the configuration of the family like a map. It is used in family therapy to engage the family, to review the pattern of the extended familiar dynamic, and to identify the difficulties in family's life (CERVENY, 2014) ${ }^{1}$. The genogram can be utilized in many fields and contexts, including to promote health, because it allows to understand the development of many dysfunctions, and diseases that affect the family. In the genogram we insert the name, the occupation, and the age of the components of the family. We also includes the degree of education, the ethnicity, the birth dates of the components, the marital status with the time of duration, the significant events in life's family, the presence of diseases in the family, the quality of the relation between the members in the family, the religion they confess, and some others information. All these data that we bring to the genogram allow us to observe the structure and the family's pattern functionality; the presence of subsystems; and the definition of its borders. Also gives to us an idea how the members of the family deal with conflicts; which are the rules they follow, when the conflict arises; and which is the role that each one of the components play in the familiar group.

\footnotetext{
${ }^{1}$ Cerveny, C. M. O. (2014). Genograma e suas aplicações com outras técnicas In:CERVENY, C.M.O. (Org.) O livro do genograma.1 ${ }^{\text {a}}$.Edição. São Paulo:Roca, 2014.
} 
Benghozi $(2010)^{2}$ studies the linkages in the genogram to observe the family's dysfunctions in the daily practical psychanalysis. The use of the genogram in family therapy was inspired in the Bowen's Family System Theory $(1979,1991)^{3}$, that presumes that the family is a system, in which, each one of the members affects the behaviour of the family as a whole. In the familiar group, each one of the components may participate from different subsystems, and may have different levels of power or functions in each one of these subsystems. As we can see, the family is defined by its story, its myths, its language, its culture and its own symbolisms, in an internal and learned speech: a repetition that begins in the childhood and that it tends to perpetuate (GEERTZ, $1978,1973)^{4}$.

The family is the place, where the self-image begins to be constructed, where we learn the family's culture language, we keep our references, while one is referencing and meaning the own world. The family is our prime social space. It will be the time that we will leave it, to reach others socials places in the way of growing up and self- individualization. Sarti (2004) $)^{5}$ says that what remains of the origins, also undergoes changes over time, and while each one of the members of the family is involved to full fit what is expected from him, also each one is walking to others paths of learning, growing up and self-individualization. The utility of the genogram as a knowledge source is due to the possibility to study the relationship between generations (CERVENY, 2005) ${ }^{6}$. When the professional will do the genogram, it is important to ask to the participant of the process, to consult the "elephants" of the family to get the information that are lost from the memory of the last generation, and that the oldest in the family can report (quotation marks from the authors). In this research we can find secrets, not resolved heartbreaks, not forgiven infidelities, or stories of pernicious familiar cohesions and triangulations. Some truths of the family are difficult to be revealed, and the visceral exposition of the family's truths could promote much emotion and anguish. Not always we like what we see: the hidden secrets travel in the following generations along the time. They are like shackles that hold us back to the past and prevent us to grow up. To be trapped in the built generational webs to full fit what the formers expected from us, also may cause some suffering.

Writing a poem about what the genogram shows, we can say that...

What I see on the genogram?

\section{Arlene Moreira}

The stories of life

Are seeing in the genogram.

May be we see

Some disruptions,

Hidden love letters,

Marital infidelities

Remembrances,

And games of power...

It is the place,

Where to love or to hate

\footnotetext{
${ }^{2}$ Benghozi, Pierre (2010). Malhagem, filiação e afiliação. Psicanálise dos vínculos: casal, família, grupo, instituição e campo social. Trad. Eunice Dutra Galery, $1^{a}$.ed. São Paulo: Vetor, 2010.

${ }^{3}$ Bowen, M [1991(1979) ]. De la família ao individuo. Barcelona, España: Paidós (Publicación original en 1979).

${ }^{4}$ Geertz, C. [ 1978 (1973) ]. O impacto do conceito de cultura sobre o conceito do homem. In C. Geertz, A interpretação das culturas (pp.45-66). Rio de Janeiro: Zahar.

${ }_{6}^{5}$ Sarti,C.A. ( 2004). A família como ordem simbólica. Psicologia USP, 2004, 15(3), 11-28.

${ }^{6}$ Cerveny, C. M.O.; Almeida Prado, A.E.F. Genograma: um desatador de Nós na construção de conhecimento. IV Congresso Brasileiro de Terapia Familiar. Brasília, 2000.
} 
Make people to play games

In daily life,

And after the dead time.

So, all the gods of Olympus

Are in scene,

Helping the family's flowers

To grow up

In the garden.

But some of them

Want to leave,

To change the facts,

So they dance,

To forget the death heroes.

They claim

To the saints of the sky

To make free the chains

They carry in their hands.

The seeds of love

Are no longer dolls.

They want to fly,

And to be free.

They want to be themselves,

And to rebuilt the paradise,

To live their lives.

The curative power of poems (?). Aristotle, in the Antiquity, had believed in the process of liberation of emotions (catharsis) in dramaturgy. We can recognise the curative power of the poem, that was experienced by Michael Lee $(1996)^{7}$, and to believe in the curative power of Bibliotherapy, Literature and Fine Arts as did Nise da Silveira $(1992,1981)^{8}$; and Caroline Schrodes $(1949)^{9}$. Then and now, we have seen many followers ${ }^{10}$ in

\footnotetext{
${ }^{7}$ Lee Michael $(1996,2006)$. Poems in the Waiting Room- PitWR. This project was founded by Michael Lee and it is a United Kingdom based and registered Art Project in health charity, that intended make the patient's wait more pleasant. It was supported by grants donations and by The Garfield Weston Foundation. Today, it has attracted wider attention, and encourages collaboration in other countries. A single A4 size format (three fold cards) with 6 or 8 poems inside are distributed to waiting rooms four times a year and the patients are invited to read and take the cards with them. A research was done after that, to take information of the results. All the patients, the nursery, the paramedics and doctors said that they had noted improve in the time and quality of the wait, and how the patients come to be attended and the way they faced their disease.

${ }^{8}$ Silveira, Nise. She was a Brazilian psychiatry who, since 1949, had been used the Fine Arts in the treatment of Schizophrenia. She founded the Museum of the Unconscious, in Rio de Janeiro, where are exposed the works from many of her patients. She has published some works, like the portuguese titles: As imagens do Inconsciente (1981), Rio de Janeiro: Alhambra; and O Mundo das Imagens (1992), São Paulo: Ática.

${ }^{9}$ Caroline Schrodes (1949) had defended the power of Bibliotherapy in the study named Bibliotherapy: a Theoretical and Clinical- experimental study. 1949. 344p. Dissertation. University of Berkeley, California.

${ }^{10}$ Some of them were: Sharma, Varun; Sood Amit; Prasad, Kavita; Loehrer Laura; Schroeder, Darrel \& Bauer, Brent (2014), who recently described Bibliotherapy to decrease stress and anxiety and increase resilience and mindfulness: a
} 
these believes, and they have been step on the top of these footprints. We can say that poetry can be a resource that put us in touch with our inner feelings, and this could be the reason why we have studied and believed in the cathartic power of Poetry and Fine Arts (MOREIRA, CERVENY, ZERBINI, 2015) ${ }^{11}$. Recently a clinical case reports the use of poetry in the Reflective Group in therapy $(2015)^{12}$ that was performed in the supervision to difficult cases. In this experience the poetry was born inspired by the report of the clinical case to a group of therapeutics. The listened narrative, the metaphors done by all the components of the group, and the feelings that flowed inside the poet were the materials to construct the poem. As a result, the verses reflected the narrative, as well the aroused feelings in the events that the client was living. This poem was given to the client, so he could read it again and again. The results of this experience is similar to that observed by Michael Lee which we related above.

The poet's work. The genogram is like a design that demands to poet colouring with words. The poetic imagination is a creative laboratory that organizes the revealed emotions presents in the narrative, which the poet apprehends in her mind. The revelation is inside the poem: maybe it reveals a new way to see the same event. The result is a poetic experience which has double face and double benefits: to whose was given and to whom was made. Foster; Mc Allister and O'Brien (2005) ${ }^{13}$ relate on their study, that to write about our own experiences also provides a self- transformation and it is like a process of self-rebuilding. Bergson (1990) ${ }^{14}$ gave to us a new way to feel the past time and to reorganise the present time, when we bring, in memory, the past facts to the present. And he explained that we actualize the past memory with our present time.

The poem in this study, is like an original picture painted with the participant's feeling, that is going to be updating by the poet, that mixes the own feelings with those who comes to the participant, while the poet is listening, and seeing what shows the mimics and the corporal status of the narrator during the narrative (the presence of silences, of tears...). All these impressions are resonate in the poet feelings, and these impressions are transported to the lines of the poetry. We must remember that the oral narrative is prior than written texts, in the original times, and it was the way how the knowledge, believes and culture were transmitted to the younger generations.

Santos Souza $(2015)^{15}$, in an auto-ethnographic study about Resilience in Family, says that when we are able to talk about our pain, it is possible too to access the level of affective suffer and to rework the feelings cognitively. In this way we are able to give sense to the past events, and it is possible to promote the cure (p.50). Santos Souza meets Cyrulnik (2013) ${ }^{16}$ 's ideas, and both are according that the ability to verbalize is the first step to transcend, and to meet the beauty of the wicked moment to beautify the bitterness, which was inscribed on the soul, when the moment was lived (p.74), as says the later one.

Pilot Trial. In: The Journal of Science and Healing (Impact Factor: 1) 07/2014; 10 (04). DOI:10.1016/.explore.2014.04.002; and also Caldin, Clarice Fortkamp with The reading as a therapeutical function: Bibliotherapy. Enc. Bibli: R. Eletr. Bibliotecon.. Ci. Inf.,ISSN1518-2924, Florianopolis, Brasil, n12,p.32-44, 2001.

${ }^{11}$ Moreira, Maria Arlene A; Cerveny, Ceneide Maria de O. \& Zerbini, Maria Irene S (2015). Poetry and Nostalgia: Living Memories in the Space of Therapy. Paper presented at NOS1. The Exploring Nostalgia Project: $2^{\text {nd }}$ Global Meeting. Friday $3^{\text {rd }}$ July- Sunday $5^{\text {th }}$ July2015. Mansfield College, Oxford, United Kingdom.

${ }^{12}$ Zerbini, M. I. S; Cerveny, C. M.O e Moreira, M. A. A (2015). La poética en la Intervisión: Crisis Y Soluciones Creativas en el espacio Terapéutico. Paper presented at the 19th. International Congress for Group Psychotherapy and Group Processes. Rovinj, Croatia, 2015.

${ }^{13}$ Foster, Kim; McAllister, Margaret; \& O'Brien, Louise (2005). Coming to Auto-ethnography: A mental health nurse's experience. International Journal of Qualitative Methods, 4 (4),2005,1-15.

${ }^{14}$ Bergson, Henri (1990). Matéria e Memória.Ensaio sobre a relação do corpo com o espírito. São Paulo: Martins Fontes, 1990.

${ }^{15}$ Santos Souza, Cinthia Barreto (2015). A Poética da Resiliência em Família. Tese de Doutorado, defendida na Pontifícia Universidade Católica de SãoPaulo, São Paulo, Brasil, 2015.

${ }^{16}$ Cyrulnik, Boris. Corra que a vida te chama: Memórias. Rio de Janeiro: Rocco, 2013. 
Adelia Prado (2006), is a Brazilian poet who says that the inspiration is an experience of a previous reality to ourselves. In it, the thought meets the emotion and releases the pain, so it is able to visualise another meaning to the lived event, in a different time than it has occurred.

\section{Methodology}

This study is a qualitative research. It involves the combination of the genogram with poetry. Ten families' stories were heard, in which the participants, in number of 10 , made a previous and a particular research with their family's older members, to bring all the story that involves, at least, the three intergenerational lines up own generation. The formatted genogram exposures the structure, the myths, and the interactions between the members, the secrets and the configuration of the family. In this study all the participants are women, and the rage of age are between 28 to 66 years old. The terms of consent to realize this study were collected. The original names, present in the poems, were removed to respect the anonymity. Each narrative was heard in accordance an attitude of respect, consideration and care, and it was illustrated by a poem. The terms, the expressions and the metaphors used were singular to particular case. At the end of the narrative, the poet asks to the participant the permission to read the poem in loud voice, and at the end of the lecture, the poem is given to them, as a gift to share their stories. So, ten written poems were based on the ten genograms.

\section{Consideration And Results}

The genograms in this study were collected and formatted in the discipline named Intergenerationality and its influence in the acquisition of knowledge, carried out by the Prof. $\mathrm{PhD}$. Ceneide de Oliveira Cerveny, from the Pontificia Universidade Catolica de São Paulo, Brazil, at the year of 2015. While the use of the genogram is an instrumental is Family Therapy, in this study we highlight the genogram to find the poetry in the families' stories. As we cited before, many authors recognise the cathartic power of the Bibliotherapy, the Literature, and the Fine Arts to perceive another angle of vision that one did not see before. The idea is not new, but is used until now. We should consider that writing poetry involves to find the right word to express the feeling. This means that is not easy make poem in a different language and culture. To write in a different language than ours, we need know not only the language, but also the culture, and the place where the narrative emerges, when it passes by, and for whom it is addressed. The lecture of feelings in the crossway between cultures, language and times requires respect. Sometimes the lack of respect is due from the ignorance about the culture, the language or/and the costumes where the people come from. Only with respect we can exposure ideas and feelings without hurting anyone. So, we think that the great poet's difficult is to write in a different language than the one of the own culture. Our hope is that the poem always finds the reborn Phoenix in the stories. So we ask permission (and excuses) to present the results that the poetry found in these stories. The presentation of the poem was made by the poet, who ask permission to recite it in loud voice, after the genogram of their family is presented. The silence is the common tonic as to see the genogram presentation, as to ear the poem made with the narrative of the genogram. All the participants are present in each one of the presentation. They all made silence to hear one by one of the presentation of the genograms and the poems. The emotion was evident. And also the happiness. The poet asked to the participants if they used to write poems. They said that make poems was not a note of habitude at their lives. Not now. Some of them confessed that they did poems, but it was in the adolescent age. Now, the life is in a rush time, and they don't stop to do this anymore.

After to receive the poems the participants gave to us some feed-backs, which we reproduce below:

I received this poem as a gift, and it was a marvellous surprise...

It seems that you know more about me than myself...

I think what beautiful things you write..., and I did not saw, until now. Now I see...

How happiness you bring to me and to others with these poems...

You see necessities that claim to be founded and nobody sees... 
You have an ability that is a gift, because you put in words the transmuted feelings...

In your poems you talk about my feelings, but it is like you show another way to see the fact...

You find in the story so many things, and you put new glasses with wisdom and with your lovely heart, and them we must to see them...

I show to my father the family's poem that you made... He cried when he read it... And he asks me a copy...

The poem that you gave to me, it made me remember that good memories arise in both: bad and good moments. It; touched myself deeply, and I thank you for that...

To finalize, and because the space is short to present all the poems, we can write about the stories in a little poem:

The stories

Arlene Moreira

I have a poem book

And I write stories in it.

They are true or not,

You don't know,

And I do not say.

But every day,

I go from the south to the north,

In my soul,

I dress my feelings

As I am painting

The words with colours,

And hope

To save the day.

\section{Bibliographic References}

[1] Cerveny, C. M. O.; Zerbini, M.I.S.; Moreira, M. A. A (2015). La poética en la Intervision: crisis y soluciones creativas en el espacio terapéutico. Presented at the19th. International Congress for Group Psychotherapy and Group Processes, Roviny, 2015;

[2] Moreira, M. A. A.; Cerveny, C. M. O.; Zerbini, M.I.S (2015). Poetry and Nostalgia: New Paths to treat living memory in the space of Therapy. Inter-Disciplinary.Net. Global Conference about Nostalgia $3^{\text {rd }}$ to 5 t of July, 2015. Mainfield College, Oxford;

[3] Zerbini, M.I.S.; Cerveny, C. M. O.; Moreira, M. A. A (2015). A Poética no Espaço Terapêutico como objeto Intermediário. Diálogos Interculturais: construindo a terapia de casal e de família. Presented at the Congress RELATES, São Paulo, 2015;

[4] Krüger, L. L; Werlang, B. S. G (2008). O Genograma como recurso no espaço conversacional terapêutico. Avaliação Psicológica, 2008, 7(3), pp. 415-426;

[5] Santarpia, A (2003). La Rappresentazione Linguistico- Poetica del Corpo. Artiterapie, 9 (3-4), 21-22;

[6] Cerveny, C. M. O; Almeida Prado, A.E.F (2000). the IV Brazilian Congress Of Familiar Therapy, Brasília, 2000;

[7] Lee Michael (2006). Poems in the waiting Room. Aspects of poetry. Journal of Poetry Therapy: The Interdisciplinary Journal of Practice, Theory, Research and Education. Vol19, Issue2, 2006. 


\section{Bio's authors.}

(1) Maria Arlene de Almeida Moreira is Medical Doctor, has Master Degree in Clinical Psychology, and is PhD student at the Pontificia Universidade Catolica deSão Paulo, Brasil.

(2) Ceneide Maria de Oliveira Cerveny has PhD in Clinical Psychology, author of many books and Professor of Post Graduated Studies at Pontificia Universidade Católica de São Paulo. 